\title{
PENGARUH LAYANAN KONSELING KELOMPOK DENGAN TEKNIK RATIONAL EMOTIVE BEHAVIOR THERAPHY DALAM MENGURANGI PERILAKU AGRESIF SISWA DARI KELUARGA DISHARMONIS
}

\author{
Utari Maharani Ningsih, Hadiwinarto, Rita Sinthia \\ Prodi Bimbingan dan Konseling Fakultas Keguruan dan Ilmu Pendidikan \\ Universitas Bengkulu \\ taribkl12@gmail.com, hadiwinarto@unib.ac.id, sinthia.rita@yahoo.com
}

\begin{abstract}
ABSTRAK
Perilaku agresif di kalangan remaja semakin marak terjadi baik verbal maupun non verbal. Tujuan penelitian yaitu menjelaskan pengaruh layanan konseling kelompok dengan teknik terapi perilaku, yaitu teknik rational emotive behavior therapy terhadap perilaku agresif siswa yang berasal dari keluarga disharmonis. Metode penelitian menggunakan eksperimen one-group pretest-posttest design. Populasi penelitian ini adalah siswa SMP N 13 kota Bengkulu berasal dari keluarga disharmonis yang memiliki perilaku agresif tinggi berjumlah 30 orang siswa. Sampel penelitian berjumlah 7 orang yang memiliki perilaku agresif tinggi. Penentuan sampel menggunakan teknik purposive sampling. Data penelitian didapat dengan menggunakan kuesioner (angket) dengan skala Likert. Reliabilitas cronbach's Alpha sebesar 0.912 berjumlah butir 30 item. Hasil analisis uji $t$ (paired sample test) yaitu, nilai $t=22.950$ dan sig (2-tailed) 0.000 yang berarti $0.000<0.05$, sehingga Ho ditolak dan Ha diterima. Setelah dilakukan treatment rata- rata skor post-test menunjukkan hasil 75,14 dengan kategori rendah yang sebelumnya rata-rata skor pre-test mencapai 112,57 dengan kategori tinggi. Hal ini berarti adanya pengaruh yang signifikan terhadap perilaku agresif setelah diberikan layanan konseling kelompok dengan teknik rational emotive behavior therapy pada siswa SMP N 13 Kota bengkulu yang berasal dari keluarga disharmonis.
\end{abstract}

Kata kunci : Perilaku Agresif, Konseling Kelompok, Keluarga Disharmonis, Teknik Rational Emotive Behavior Therapy.

\section{EFFECT OF GROUP COUNSELING SERVICES WITH RATIONAL EMOTIVE BEHAVIORTHERAPY TECHNIQUES ON REDUCING THE AGGRESSIVE BEHAVIOR OF STUDENTS FROM DISHARMONY FAMILIES}

\begin{abstract}
Aggesive behavior among teenagers is increasingly widespread both verbally and nonverbaly. This study aimed to describe the effect of group counseling services with rational emotive behavior therapy technique on the aggressive behavior from the students who come from disharmony families. This research was an experiment with a one group pretest-posttest design. The population in this study were 30 students of SMP N 13 Bengkulu city who came from disharmony families who chose high aggressive behavior. The sample of this study were 7 students who have high aggressive behavior. Samples were taken by purposive sampling technique. The data collection technique in this study used a questionnaire with Likert scale. Cronbach's Alpha reliability in this study was 0.912 with a total of 30 items. The data analysis technique used the $t$ test (paired sample test). The results of the $t$ test show the value of $t=22.950$ and sig (2-tailed) 0.000 which means $0.000<0.05$, so Ho is rejected and Ha is accepted. After group counseling services were carried out, the average post-test score showed 75.14 in the low category, previously the average pre-test score reached 112.57 in the high category. It means that in this study there was a significant influence on aggressive behavior after being given group
\end{abstract}


counseling services with traditional emotive behavior therapy techniques in students of SMPN 13 Bengkulu city who come from disharmony families.

Keywords $\quad$ : Aggresisive Behavior, Group Counseling, Disharmony Families, Rational Emotive Behavior Therapy Tecnique.

\section{PENDAHULUAN}

Dewasa ini perilaku agresif di kalangan remaja makin marak terjadi baik itu ti ${ }^{27}$, yang dilakukan secara verbal maupun non verbal. Perilaku agresif adalah ekspresi emosional dari kegagalan pribadi, yang sengaja diungkapkan dalam bentuk penggunaan bahasa dan perilaku non-verbal untuk menghancurkan orang atau benda. Susantyo (dalam Rahayu, 2018:319).

Perilaku agresif verbal dan non-verbal telah banyak menyebabkan insiden di lingkungan sekitar saat ini, mulai dari cacian makian, kriminalitas, bahkan pembunuhan pun dapat terjadi karena adanya perilaku agresif.

Buss dan Perry (dalam Palinoan, 2015:108) menjelaskan bahwa ada 4 karakteristik dari perilaku agresif yaitu perilaku agresif fisik, perilaku agresif verbal, kemarahan dan permusuhan. Agresi fisik adalah ketika seseorang memukul, mencakar, atau menggigit orang lain, termasuk memukul, menendang, menusuk, membakar, dll. Agresi verbal adalah penggunaan kata-kata dengan cara yang berbahaya dan agresif. Ketika seseorang mengumpat, membentak, membantah, mengolok-olok, dan sebagainya, dapat dinyatakan melakukan agresi verbal. Ketika seseorang merasa marah, dia merasa frustrasi atau tersinggung. Kemarahan atau perasaan marah merupakan tindakan yang tidak memiliki tujuan dan hanya perasaan. Permusuhan adalah perasaan tidak suka dan ketidakpercayaan terhadap orang lain, seringkali karena ancaman yang dirasakan terhadap harga diri seseorang.

Perilaku agresif memang semakin sering terjadi, dapat dilihat dari penelitian yang dilakukan oleh Herawati (2014:5) dengan judul "Hubungan Kecerdasan Emosional dengan Perilaku Agresif Siswa Kelas X TM (Teknik Mesin) SMKN 2 Kota Bengkulu”, yang menunjukkan bahwa ada satu kasus yang terjadi pada salah satu siswa SMKN 2 Kota Bengkulu yang berkaitan dengan perilaku agresif dan kontrol emosional yaitu pada hari Jumat, 17 Januari 2014 telah terjadi tawuran antara siswa STM dengan siswa SMA plus 7 Kota Bengkulu.

Perilaku agresif semakin sering terjadi di kalangan siswa baik yang dilakukan secara 
verbal maupun non verbal, serta yang terjadi karena adanya pengaruh dari luar maupun dari dalam lingkungan individu, bahkan perilaku agresif dapat ditimbulkan oleh orang terdekat individu, seperti pengaruh dari dalam yaitu keluarga. Keluarga dapat menjadi salah satu faktor pemicu timbulnya perilaku agresif seorang anak. Keluarga adalah sekelompok orang yang tergabung dan hidup bersama karena hubungan darah, hubungan pernikahan atau pengangkatan dalam kurun waktu yang lama.

Keharmonisan suatu keluarga paling utama kedua orang tua sangat berarti dalam mendidik seseorang anak guna berkembang serta tumbuh dan sanggup berhubungan dengan baik dengan lingkungan sekitar. Keluarga yang harmonis bisa membuat anak merasa senang serta dekat dengan orang tua. Keluarga ialah aspek dini terbentuknya ketidakseimbangan pada masa anak muda. Realitas menampilkan jika tidak seluruh keluarga sanggup membawa kebahagiaan untuk seluruh anggotanya. Banyak keluarga yang alami disharmonis, keluarga disharmnonis sangat berpengaruh dalam sesuatu perkembangan serta pertumbuhan anak, lebih- lebih dalam pendidikan (Astorini dan Muhari, 2014:188)

Seluruh keluarga di muka bumi pastinya menginginkan keluarga yang bahagia dan memiliki keluarga yang utuh, menurut Hurlock (1980:299), keluarga yang harmonis berasal dari hubungan antara suami istri, anak dan anggota keluarga lainnya yang saling mencintai dan memperoleh kebahagiaan bersama. Mereka menerima perannya masingmasing dan membuat keputusan yang berasal dari peran yang mereka mainkan. Seluruh anggota keluarga yang merasakan kebahagiaan dan kurangnya rasa kekecewaan disebut keluarga harmonis.

Keluarga harmonis tentunya sangat diidamkan oleh banyak orang, tapi pada kenyataan yang sebenarnya, banyak sekali keluarga yang mengalami ketidak harmonisan dalam menjalani kehidupan berkeluarga. Menurut Willis (2009:13), ketidakharmonisan yakni kehidupan keluarga yang struktur keanggotaannya masih lengkap, namun dalam anggota keluarga terdapat minimnya atensi, minimnya komunikasi, anggota keluarga mempunyai kehidupan yang penuh tekanan serta pertengkaran selalu antara ayah dan ibu, yang bisa menimbulkan pertengkaran keluarga, bahkan perceraian. Sedangkan menurut Handayani (2013:30), sebuah keluarga disebut disharmoni jika ada satu atau lebih anggota keluarga yang hidupnya dipenuhi konflik, ketegangan, frustasi dan tidak pernah merasa puas dan bahagia dengan keadaan dan keberadaannya. Situasi ini berkaitan dengan kegagalan atau ketidakmampuan untuk beradaptasi dengan lingkungan. Keadaan keluarga yang disharmonis menimbulkan dampak negatif disetiap anggota keluarga. Keluarga yang 
disharmonis dapat menjadi salah satu faktor terbentuknya perilaku agresif pada anggota keluarga terutama pada seorang anak atau remaja yang ada di dalam keluarga, karena pada dasarnya apapun hal yang tidak mengenakkan terjadi di dalam keluarga akan menimbulkan tekanan-tekanan pada setiap anggota keluarga.

Berdasarkan pengamatan penulis selama 2 bulan dalam kegiatan magang II di SMP N 13 Kota Bengkulu, perilaku agresif merupakan salah satu permasalahan yang hampir setiap hari ditemui. Beberapa siswa adalah mereka yang memang dari kalangan keluarga yang disharmonis seperti, siswa yang orang tuanya bercerai, siswa yang kedua orang tuanya berkelahi terus menerus, siswa tidak tinggal bersama orang tuanya, siswa yang kurang perhatian dari orangtuanya dan ada pula siswa yang keluarganya terlalu keras dalam mendidik. Remaja melakukan perilaku-perilaku yang memang dianggap menyimpang seperti perkelahian antar teman sekelas, menyerang teman yang lebih lemah, berkata kasar, bahkan mereka ada yang menyakiti temannya dengan unsur disengaja.

Kejadian seperti inilah yang membuat siswa menjadi pribadi yang lebih agresif, oleh karenanya perlu tindakan pencegahan bahkan pengentasan perilaku-perilaku agresif yang dilakukan siswa, sebab apabila tidak diatasi atau ditindak lanjuti akan berdampak fatal bagi siswa, seperti terciptanya hubungan sosial yang kurang sehat, konsep diri siswa menjadi buruk serta kesulitan dalam konsentrasi belajar. Oleh sebab itu butuh penindakan spesial guna menanggulangi siswa yang mempunyai sikap yang kasar semacam ini. Salah satu layanan yang pas guna menanggulangi kasus semacam ini merupakan lewat layanan bimbingan serta konseling yang terdapat di sekolah.

Aktivitas layanan Konseling Kelompok diharapkan bisa dicoba dengan sebaikbaiknya serta seefektif mungkin, sehingga sanggup menggapai tujuan yang diharapkan, oleh sebab itu dibutuhkan sesuatu metode dalam penerapan konseling kelompok. Metode REBT yang dibesarkan oleh Albert Ellis pada pertengahan tahun 1950- an ialah sesuatu proses yang bisa membetulkan serta mengganti anggapan, pemikiran, kepercayaan, serta pemikiran., Orang yang irasional serta tidak logis jadi rasional serta logis. Pendekatan REBT berupaya mengenali kepercayaan irasional seorang dan setelah itu menantang mereka untuk menciptakan metode berpikir yang lebih logis ataupun rasional. (Erlina dan Sari 2019:304).

Layanan Konseling Kelompok yang dilengkapi dengan teknik Rational Emotive Behavior Therapy ini dapat menjadikan suasana dalam kelompok menjadi lebih kekeluargaan karena setiap anggota dapat merasakan perasaan yang sama yang mereka alami, sehingga mereka dapat saling memberikan dukungan dan motivasi kesesamanya 
karena pada dasarnya mereka memiliki masalah dan keadaan yang sama.

\section{METODE PENELITIAN}

Desain penelitian ini ialah desain penelitian kuantitatif dengan prosedur eksperimen. Penelitian dicoba dengan memakai desain satu kelompok pretest- posttest( one group pretest- postest design)

Pada kelompok tersebut dicoba 2 kali pengukuran, pengukuran yang pertama ( pretest) dicoba untuk melihat keadaan ilustrasi ialah sikap kasar siswa dari keluarga disharmonis saat sebelum diberikan layanan tutorial kelompok dengan metode rational emotive behavior therapy ( REBT), serta pengukuran kedua( post- test) dicoba untuk memandang sikap kasar siswa dari keluarga disharmonis setelah diberikan layanan konseling kelompok dengan metode rational emotive behavior therapy ( REBT) .

Populasi dalam penelitian ini adalah 30 siswa yang berasal dari keluarga disharmonis SMP NEGERI 13 Kota Bengkulu. Adapun sampel dari penelitian ini sebanyak 7 orang siswa perilaku agresifnya tinggi yang berasal dari 30 siswa yang berlatar belakang keluarga disharmonis. Pengambilan sampel pada penelitian ini menggunakan teknik purposive sampling yakni memberikan angket perilaku agresif yang telah disediakan kepada populasi.

Metode pengumpulan data yang digunakan dalam penelitian ini adalah angket, yang dilakukan dengan mengajukan pertanyaan atau membuat pernyataan kepada responden untuk dijawab. Peneliti menggunakan angket skala likert, memiliki lima alternatif jawaban, yaitu Selalu (SL), Sering (SR), Kadang-kadang (K), Jarang (JR) dan Tidak Pernah (TP). Konseli hanya memberikan tanda (x) pada jawaban yang dianggap tepat. Angket perilaku agresif ini digunakan untuk mengukur tingkat agresifitas siswa dari keluarga disharmonis di SMP N 13 Kota Bengkulu.

Pengujian validitas menggunakan validitas isi,. Uji validitas pada penelitian ini diperoleh melalui konsultasi kepada para ahli untuk diteliti dan di evaluasi secara sistematis pada setiap item angket. Dalam penelitian ini instrumen divalidasi oleh dua validator (ahli). Selanjutnya butir angket diuji coba ke non populasi/sampel, selanjutnya di olah melaui program aplikasi SPSS 25.0. Berdasarkan uji validasi ahli jumlah butir angket yang awalnya berjumlah 53 butir menjadi 44 butir, dan setelah di uji coba dan di olah menggunakan SPSS menjadi 30 butir item valid. Uji reliabilitas dilakukan dengan membandingkan angka cronbach alpha dengan ketentuan nilai cronbach's alpha minimal 0,6 artinya jika nilai cronbach alpha yang diperoleh dari hasil perhitungan SPSS lebih 
besar dari 0,6 maka disimpulkan kuesioner reliabel. Nilai alpha penelitian ini adalah 0,912 yang berarti angket perilaku agresif reliabel.

\section{HASIL DAN PEMBAHASAN}

Penentuan kategori penilaian bagi siswa yang berperilaku agresif tinggi diawali dengan menentukan mean dan standar deviasi, nilai mean yaitu 90 dan standar deviasi yaitu 20 dengan skor minimal 30 dan maksimal 150 dengaan menggunakan 5 kategori yakni sangat tinggi, tinggi, sedang, rendah dan sangat rendah. Menurut perhitungan, kategori dan hasil prediksi interval ditunjukkan pada tabel.

\section{Tabel 1}

Frekuensi pre-test tingkat agresifitas siswa

\begin{tabular}{cccc}
\hline Interval & Frekuensi & Kategori & persentase \\
\hline$>\mathbf{1 2 0}$ & 0 & Sangat tinggi & $0 \%$ \\
$\mathbf{9 1 - 1 1 9}$ & 13 & Tinggi & $43 \%$ \\
$\mathbf{8 1 - 9 0}$ & 7 & Sedang & $23 \%$ \\
$\mathbf{6 1 - 8 0}$ & 8 & Rendah & $27 \%$ \\
$<\mathbf{6 0}$ & 2 & Sangat rendah & $7 \%$ \\
Total & $\mathbf{3 0}$ & & \\
\hline
\end{tabular}

Berdasarkan tabel, dilihat bahwa siswa yang mempunyai perilaku agresif dengan kategori sangat tinggi sebesar $0 \%$, siswa dengan kategori tinggi sebesar $43 \%$ yaitu sebanyak 13 orang, siswa dengan kategori sedang dengan persentase sebesar 23\%, siswa dengan kategori rendah sebesar $27 \%$ yaitu sebanyak 8 orang dan siswa dengan kategori sangat rendah sebesar 7\% dengan jumlah 2 orang. Layanan konseling kelompok dengan teknik rational emotive behavior therapy diberikan pada sampel yang diambil berdasarkan hasil pre-test dengan skor tertinggi yaitu berjumlah 7 orang dilakukan sebanyak 7 kali pertemuan. Setelah pemberian layanan konseling kelompok dengan teknik REBT, selanjutnya dilakukan post-test yaitu pemberian angket perilaku agresif yang sama pada saat pre-test kepada 7 orang siswa.

\section{Tabel 2}

Frekuensi Post-test Tingkat Perilaku Agresif Siswa

\begin{tabular}{cccc}
\hline Interval & Frekuensi & Kategori & persentase \\
\hline$>\mathbf{1 2 0}$ & 0 & Sangat tinggi & $0 \%$ \\
$\mathbf{9 1 - 1 1 9}$ & 0 & Tinggi & $0 \%$ \\
$\mathbf{8 1 - 9 0}$ & 0 & Sedang & $0 \%$ \\
$\mathbf{6 1 - 8 0}$ & 7 & Rendah & $100 \%$ \\
$<\mathbf{6 0}$ & 0 & Sangat rendah & $0 \%$ \\
Total & 7 & & \\
\hline
\end{tabular}

Berdasarkan tabel 2 di atas, setelah diberikan layanan konseling kelompok hasil 
post-test menunjukkan siswa kategori rendah berjumlah 7 orang dengan persentase $100 \%$. Hasil post-test 7 orang sampel menunjukkan adanyapenurunan tingkat perilaku agresif menjadi kategori rendah .Perbandingan skor dan mean 7 orang sampel sebelum dan setelah di berikan treatment dilihat pada tabel di bawah ini.

Tabel 3

Perbandingan Skor Pre-test dan Pos-test Tingkat Agresifitas Siswa yang Berasal dari Keluarga Disharmonis

\begin{tabular}{ccccccc}
\hline No & Responden & Pre-test & Kategori & Post-test & kategori & Penurunan \\
\hline $\mathbf{1}$ & F & 107 & Tinggi & 77 & Rendah & 30 \\
$\mathbf{2}$ & ME & 115 & Tinggi & 71 & Rendah & 44 \\
$\mathbf{3}$ & JN & 114 & Tinggi & 77 & Rendah & 37 \\
$\mathbf{4}$ & ED & 112 & Tinggi & 73 & Rendah & 39 \\
$\mathbf{5}$ & HA & 115 & Tinggi & 79 & Rendah & 36 \\
$\mathbf{6}$ & DA & 112 & Tinggi & 76 & Rendah & 37 \\
$\mathbf{7}$ & SA & 113 & Tinggi & 73 & Rendah & 40 \\
& Rata-rata & 112,57 & Tinggi & 75,14 & Rendah & 37,57 \\
& Jumlah & 788 & & 526 & & 263 \\
& Tertinggi & 115 & & 79 & & \\
& Terendah & 107 & & 71 & & \\
\hline
\end{tabular}

Berdasarkan tabel 3 di atas siswa yang memiliki tingkat agresifitas tinggi yang berasal dari keluarga disharmonis setelah diberikan treatment mengalami penurunan dengan ratarata nilai sebelum diberi layanan sebesar 112,57 yang termasuk kedalam kategori tinggi, setelah diberikan layanan konseling kelompok mengalami penurunan skor dengan mean sebesar 74,14 yang termasuk ke dalam kategori rendah.

Peneliti menggunakan uji $t$ yang diolah dengan SPSS 25.0 untuk mengetahui ada tidaknya pengaruh yang signifikan antara layanan konseling kelompok dengan tingkat perilaku agresif siswa yang berasal dari keluarga disharmonis. Uji $t$ dalam penelitian ini ditunjukkan pada tabel 4 di bawah.

Tabel 4

Hasil Uji Sampel $t$ tes Angket Perilaku Agresif

\begin{tabular}{lll}
\hline & $T$ & Sig. (2-tailed) \\
\hline Pre-test-Post-test & 22.950 & .000
\end{tabular}

Berdasarkan tabel 4 di atas diketahui hasil Sig.(2-tailed) $=0,000$, apabila nilai sig.(2-tailed)<0,05 maka Ho ditolak, namun apabila nilai sig.(2-tailed)>0,05, maka Ha 
diterima. Maka dapat ditarik kesimpulan adanya pengaruh layanan konseling kelompok dengan teknik REBT sebagai upaya untuk menurunkan tingkat agresifitas siswa yang berlatar belakang keluarga disharmonis SMP N 13 Kota Bengkulu.

Hasil penelitian yang relevan dengan penelitian ini adalah dari Rian Affandi 2017 dengan judul “pengaruh layanan Konseling Kelompok teknik Rational Emotif Behavior Therapy (home work) untuk mengurangi perilaku agresif pada siswa kelas VII SPM Negri 2 Kotagajah Lampung Tengah Tahun Pelajaran 2016/2017”. Hasil penelitian ini menujukkan bahwa rata-rata perilaku agresif fisik, verbal, kemarahan dan permusuhan siswa setelah adanya layanan konseling kelompok lebih rendah dibandingkan sebelum menerima layanan konseling kelompok

Perilaku agresif merupakan bentuk perilaku yang timbul karena adanya rangsangan baik dari dalam maupun dari luar lingkungan seseorang. Buss dan Perry menjelaskan bahwa perilaku agresif adalah perilaku atau kecenderungan perilaku yang bermaksud merugikan orang lain, baik secara fisik maupun psikis untuk mengungkapkan perasaan negatif sehingga dapat mencapai tujuan yang diinginkan. (dalam Rahayu, 2018:319). Banyak sekali faktor yang mempengaruhi perilaku agresif diantaranya seperti, faktor psikologis, faktor sosial, faktor lingkungan, dan faktor psikososial. Herawati (2017: 86) menjelaskan salah satu faktor yang mempengaruhi terbentuknya perilaku agresif adalah kecerdasan emosional. Herawati (2018:347) juga menjelaskan beberapa hal yang mempengaruhi agresifitas seseorang adalah dari diri individu sendiri, perbedaan individu seperti status sosial ekonomi, lingkungan hidup, tekanan sosial, seks, pengaruh teman, pengaruh media, dan hubungan keluarga.

Perilaku agresif banyak terjadi dikalangan siswa baik itu terjadi karena adanya pengaruh dari luar maupun dari dalam lingkungan siswa itu sendiri seperti keluarganya, keluarga merupakan suatu kelompok orang yang terikat karena adanya hubungan darah atau pernikahan yang hidup bersama. Kehidupan keluarga yang harmonis tentunya sangat diidamkan oleh suatu keluarga, keluarga yang disharmonis sangat berperan dalam membentuk perilaku seorang anak dalam keluarga. Kenyataan menunjukkan bahwa tidak semua keluarga mampu menciptakan kebahagiaan bagi seluruh anggota keluarga, banyak keluarga yang mengalami ketidakharmonisan. Disharmoni keluarga sangat berpengaruh terhadap tumbuh kembang anak, terutama dalam bidang pendidikan (Astorini dan Muhari, 2014:188).

Pemberian layanan konseling kelompok yang diberikan kepada siswa bertujuan untuk mengurangi tingkat agresifitas yang siswa miliki. Menurut Prayitno dan Amti (1994:99) 
Konseling kelompok adalah suatu proses pemberian bantuan yang dilakukan oleh seorang ahli kepada seseorang atau beberapa individu, baik anak-anak, remaja, maupun orang dewasa agar orang yang dibimbing dapat mengembangkan kemampuannya dan mandiri, dengan memanfaatkan kekuatan individu dan fasilitas yang ada berdasarkan norma yang berlaku.

Pelaksanaan konseling kelompok pada penelitian ini diterapkan REBT. Albert (dalam Thahir dan Rizkiyani 2016:200) mengungkapkan bahwa teknik Rational Emotive Behavior Therapy adalah desain terapeutik, dalam konseling atau psikoterapi, penggunaan desain ini menekankan pemikiran irasional sebagai tujuan terapeutik, menekankan pada modifikasi atau perubahan keyakinan irasional. Dapat disimpulkan bahwa teknik rational emotive behavior therapy merupakan teknik yang tujuannnya untuk mengubah pikiran irasional seseorang menjadi rasional. Teknik ini diterapkan pada sampel sebanyak 7 kali pertemuan, yang membahas masalah dari masing-masing konseli

Hasil ini menunjukkan bahwa terdapat pengaruh layanan konseling kelompok dengan teknik Rational emotive behavior therapy untuk menurunkan tingkat perilaku agresif siswa dari keluarga disharmonis.Hasil dari skor pre-test dan post-tets juga menunjukkan bahwa perilaku agresis siswa yang semula termasuk ke dalam ketegori tinggi menjadi menurun setelah diberikan treatmen

Pelaksanaan penelitian ini dilaksanakan sesuai dengan prosedur ilmiah, namun demikian peneliti menyadari keterbatasan yang dialami dalam melaksanakan pelayanan. Penelitian ini dibatasi pada variabel-variabel yang berhubungan dengan penelitian tentang perilaku agresif siswa yang berasal dari keluarga yang tidak harmonis. Sampel penelitian dibatasi pada 7 siswa yang memiliki perilaku agresif tingkat tinggi berdasarkan angket perilaku agresif.

\section{KESIMPULAN}

Tingkat agresifitas siswa dari keluarga disharmonis sebelum diberikan layanan konseling kelompok dengan teknik REBT tergolong tinggi dengan persentase $100 \%$ dapat dilihat dari skor pre-test yaitu rata-rata skor mencapai 112,57. Tingkat agresifitas siswa dari keluarga disharmonis setelah diberikan treatment mengalami penurunan, dapat dilihat dari hasil pos-test yang menunjukkan skor 75,14 dengan kategori rendah.adanya perbedaan dan perubahan yang signifikan setelah diberikan treatment berupa layanan konseling kelompok. 
Berdasarkan penelitian ini, saran yang dapat peneliti berikan yaitu, agresifitas memiliki dampak yang sangat buruk terhadap perkembangan siswa, oleh karena itu diharapkan pihak sekolah dapat lebih memperhatikan perilaku setiap siswanya serta memfasilitasi guru BK di sekolah agar program-program dapat terlaksana dengan baik. Bagi Konselor dan Guru Bk, penelitian ini diharapkan dapat meningkatkan pelayanan bimbingan dan konseling di sekolah khususnya mengurangi perilaku agresif siswa serta masalah-masalah yang lain yang menghambat perkembangan siswa, bagi peneliti selanjutnya penelitian ini diharapkan dapat dapat memberikan gambaran dan dapat menjadi referensi yang berkaitan dengan perilaku agresif, semoga dapat digunakan dengan sebaik-baiknya.

\section{DAFTAR PUSTAKA}

Affandi R, 2017. Pengaruh Layanan Konseling Kelompok Teknik Rational emotive Behavior Therapy (home work) untuk Mengurangi Perilaku Agresif Pada Siswa Kelas VII . Universitas Lampung. Bandar Lampung.

Astorini, Muhari. 2013. Hubungan Antara Keluarga Disharmonis dan Motivasi Belajar dengan Prestasi Belajar pada Siswa Kelas X dan XI SMA NEGERI 1 Kutorejo Mojokerto. Jurnal BK. UNESA. Vol 1 no 2. Hal 187-193

Buss \& Perry, 1992. The Aggresion Questionsire, Journal of Personality and Social Psychology. The American Psychology Association. University of Texas at Austin. Vol 63 no 3. Hal 452-459

Erlina dan Sari. 2016 Pengaruh Pendekatan Rational Emotive Behavior Therapy (REBT) Terhadap Peningkatan Kecerdasan Emosional Pada Peserta Didik kelas VIII SMPN 6 Bandar Lampung Tahun Ajaran 2015/2016. Jurnal Bimbingan dan Konseling. IAIN Raden Intan Lampung. Vol 3 no 2. Hal 303-216

Herawati, 2014. Hubungan Antara Kecerdasan Emosional Dengan Perilaku Agresif Siswa Kelas x TM (Teknik Mesin) SMKN 2 Kota Bengkulu. Universitas Bengkulu. Bengkulu

Herawati, Dharmayana dan Sholihah. 2017. Kecerdasan Emosional dan Perilaku Agresif Siswa Vokasi. Jurnal Triadik. Universitas Bengkulu, Bengkulu. Vol 16 no 1. Hal 84-91

Herawati. 2018. The Students' Aggressiveness in Senior High School Based on Gender. Jurnal ICESST. Universitas Negeri Padang. Padang.

Hurlock. 1980. Perkembangan Anak Jilid 2. Jakarta. Erlangga

Handayani dkk, 2008. Psikologi Keluarga.Surabaya. Unit Penelitian dan Publikasi Psikologi Fakultas Psikologi. Universitas Surabaya. 
Palinoan, 2015. Pengaruh Konformitas dengan Agresifitas pada Kelompok Geng Motor di Samarinda. Ejournal Psikologi. Vol 3 no 2. Hal 173-185

Prayitno dan Amti,1994 dan 2013. Dasar-dasar Bimbingan dan Konseling. Jakarta : Rineka Cipta.

Rahayu, 2018. Pengaruh Pola Asuh Orang Tua dan Kontrol Diri Terhadap Perilaku Agresif pada Remaja SMP N 2 Samarinda.Jurnal Psikologi. Universitas Mulawarman. Samarinda. Vol 6 no 2. Hal 257-266

Susantyo, 2011. Memahami Perilaku Agresif : Sebuah Tinjauan Konseptual. Jurnal informasi. Penang Malaysia. University Sains Malaysia (USM). Vol 16 no 3. Hal 189-202

Thahir \& Rizkiyani, 2016. Pengaruh Konseling Rational Emotive Behavior Therapy (REBT) dalam Mengurangi Kecemasan Peserta Didik Kelas VIII SMP Gajah Mada Bandar Lampung. IAIN Raden Intan Lampung. Jurnal BK. Vol 3 No 2. Hal 197206 